\title{
A Team Production Theory of Canadian Corporate Law
}

\author{
STEPHANJE BEN-ISHAI
}

The article applies the Team Production Theory developed by American conporate law scholars. Margaret Blair and Lymn Stout, to argut that Canadian corporate law's understanding of public corporations that are not controlled by a single shareholder or group of shareholders reflects a director primacy norm rather than a shareholder primacy norm. Canadian corporate law provides that directors of such public corporations with widely-held share ownership and voting righs are free from direct control by any corporate stakeholders. A potemial departing poin for Canadian corporate law, the oppression remedy. continues to develop io deal with extra-legal advamages rooted primarily in imequal power relations among corporate stakeholkers. However, in its current and prediched future applications, the oppression remed does not provide any given stakeholder group with an abiling io dominate the boards of public corporations and obviate the director primacy norm.

The article suggests that because the director primacy norm accurately describes Camadian corporate law: further consideration needs to be given to corporate law's relative relevance in dictating how Canadian corporations currently operate.
Cet article a trait $\dot{a}$ la theorie de la production d'equipe développec par des endiss dit droit amiricain dess socicites, notammem .Margaret Blair ef Lym Stom, di sonoir que les sociefes ownertes qui me som pas contrilies par un seal acriommaire on an groupe d'actionmaires reflevent plato la norme de fa primouté des administrateurs que celle de la primunte des actitunnaires. Le droir canadien des societcs stipule que las administrateurs des sociètes ouvertes avec un grand nombre d actionnaires et de drois de vole son libres din controle direct des intervenams des socicits. Eicment point de depart pour le droit canadien des sociciss. le remede a f'oppression cominue a se developper en we de stuifer avec les arantages extrojudiciaires ancres princijulement dans les relations de powroir inegales entre les intericenants des sociere's. Cependani. dans ses applications actucelles ef préucs. le remide de l'oppression ne foumil à aucull groupe d'imernenants donmé la capacilé de dominer les conseils dadministration des sociélés ouvertes et d'iviter ainsi la norme de la primaute des adminisiruteurs.

L. 'article suggè que prisque la norme de la primank' des administronewrs decrit bien le droit cantudien des socicites. If faut examiner davamage la pertinence relarive dit droit des socicies sur te mode de regie actuel dex sociches canadiennes.

\section{TABLE OF CONTENTS}

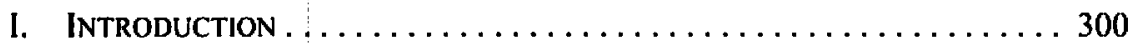

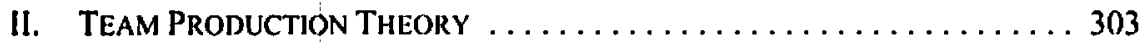

III. Team Production Theory and Canadian Corporate law . . . . . 305

A. Corporate Personality and the Di:RIVAtivi: ACtion . . . . 306

B. StATUTORY DUtIES . . . . . . . . . . . . . . . . . . . . . . 309

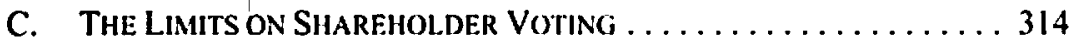

IV. Team Productión Theory and the Canadian

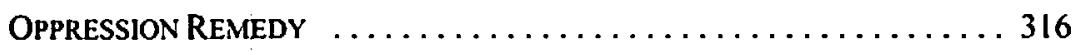

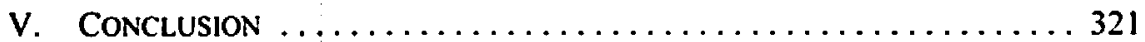

Assistant Professor, Osgonde Hall Law School, York Universily, Toronto, Canada. Geotr Mowalt provided excellent rescarch assistanee. I am grateful for the constructive and challenging questions posed by colleagues at the 2005 Canadian Law and Fconomics Association Annual Conference in Law and Economics. I am also grateful to Peer Zumbansen, Lynn Stout, Margaret Blair, and the two anonymous reviewers for comments on an carlicr draft of this article. 


\section{INTRODUCTION}

The most recent Supreme Court of Canada decision concerning corporate governance, Peoples Depariment Siores Inc. (Trustee of) $v$. Wise, ${ }^{1}$ has been both criticized and applauded on the basis that it represents a significant departure from the traditional understanding of the legal role of directors of Canadian public companies. ${ }^{2}$ Peoples centered on Wise Stores and the Wise brothers. Wise Stores was founded in 1930 by Alex Wise, who opened a small retail-clothing store in Montreal, Quebec. Alex Wise had three sons, each of whom joined his business when they came of age. In 1986, Wise Stores, by now a chain of department stores, went public and was listed on the Montreal Stock Exchange. In 1992, Wise Stores acquired the troubled Peoples chain from M\&S, which was itself owned by the British company, Marks and Spencer. Upon acquisition, Peoples became a wholly-owned subsidiary of Wise Stores, and the three Wise brothers became the sole directors of Peoples. The Toronto Dominion Bank (TD) and M\&S financed the purchase and took security interests in the assets of Peoples.

In an effort to rationalize operations, the Wise brothers began consolidating the overlapping corporate functions of Wise Stores and Peoples. Numerous problems surfaced and ultimately the brothers decided upon an inventory procurement policy such that Peoples would make all purchases from North American suppliers, while Wise Stores would make all purchases from overseas suppliers. The difficulty with this arrangement was that approximately 82 percent of the combined inventory of the companies was purchased from North American suppliers, inevitably meaning that Peoples would be extending significant trade credit to Wise Stores.

Despite efforts to rationalize operations, the fragile financial position of Peoples and Wise Stores continued. Following the presentation of financial statements showing poor results for Peoples' third fiscal quarter, M\&S initiated bankruptcy proceedings against both Wise Stores and Peoples. In response, a notice of an intention to make a proposal under the Bankriptcy and Insolvency $\mathrm{Acr}^{3}$ was filed on behalf of Peoples the same day. However, the following month Peoples consented to the bankruptcy petition filed by M\&S, and both Wise Stores and Peoples were declared bankrupt on 13 January 1995.

2004 SCC 68, [2004] 3 S.C.R. 461 [Peoples].

For an example of the criticism, see Allan C. Hutchinson, "A Not-So-Wise Decision" [forthcoming. manuscript on hand with author] [Hutchinson, "A Not-So-Wise Decision"]. For an example of the applause, see Bob Milnes. "Case Comment" (2005) 20.3 B.F.L.R. 148. For a more general evaluation of the decision sct: Catherine lirancis, "Peoples Depariment Stores Inc. v. Wise: The Expanded Scope of Directors' and Otlicen' Fiduciary IJuties and Duties of Care" (2005) 41 Can. Bus. L.J. 175; Wayne D. Gray, "A Solicitur's Perspective on Peoples v: Wise" (2005) 41 Can. Bus. L.J. 184; Warren Grover. "The Tangled Web of the Irise Casce" (2005) 41 Can. Bus. L.J. 200; Ian B. Lee. "Peoples Departmen! Stores v. Wise and the "Best Interests of the Corporation"' (2005) 41 Can. Bus. L.J. 212; Stiphane Rousseau, "Directors" Duty of Care after Peoples: Would It Be Wise to Start Worrying about Liability?" (2005) 41 Can. Bus. L.J. 223: and Jacob S. Ziegel, "The Peoples Judgment and the Supreme Court's Role in Privatc Law Cases" (2005) 41 Can. Bus. L.J. 236.

$3 \quad$ R.S.C. 1985 , c. B-3. 
Peoples' unsecured suppliers, whose claims were largely purchased by vulture funds, represented the majority of the creditors whose claims were not paid in full in the Peoples bankruptcy. The entire balance of the purchase price owed to M\&S, the full outstanding debt owed to TD, and almost all of the landords' lease claims were satisfied from the assets of Wise Stores and Peoples. The vulture funds that purchased the unsecured suppliers' claims argued that the Wise brothers, as directors of Pcoples, breached their statutory fiduciary duty and duty of care in adopting the inventory procurement policy to the detriment of the unsecured suppliers. The Supreme Court upheld the Quebec Court of Appeal's finding that the Wise brothers had not breached their fiduciary duty or duty of care in adopting the inventory procurement policy. In reaching this decision, the Supreme Court held that " $[t]$ he interests of the corporation are not to be confused with the interests of the creditors or those of any other stakeholders."

Widespread current thinking among the Canadian legal community supports the view that Peoples is an unjustified departure from Canadian corporate law's principal-agent, sharcholder primacy understanding of the board of directors' role in public corporations. It is on the basis of this shareholder primacy understanding of the existing legal role of directors of public corporations that over the last decade Canadian academics, lawyers, and the judiciary have put forward diverging normative visions of what the legal role of directors should be. At one end of the spectrum is the most common account provided by law and economics scholars and others adopting a principal-agent model, where directors' sole duty is to maximize the wealth of the shareholders, who are the owners of the corporation. According to this account, other corporate stakeholders should be left to protect their own interests by bargaining for the best returns that they can. At the other end of the spectrum, less popular rival progressive accounts suggest that directors should owe duties to all of the corporation's stakeholders. ${ }^{7}$ These accounts have generally accepted that the principle-agent, shareholder primacy model is currently operating in Canadian corporate law, but call for legal reforms so that corporations can be made to run with due regard for corporate stakeholders such as employees, creditors, customers, suppliers, and local communities. ${ }^{8}$ While widely rejected in academic and legal circles, such rival accounts have found support

Milnes, supro note 2. Vulture funds are asset-based funds that invest in distressed debt or other securities issued by companies in default or in banknuptcy. Vulture funds are rclatively new players on the Canadian bankruptey and reorganization landscape. Ste Justin R. Fogarty, "Vulture Culture: The Changing Dynamies of the CCAA \& BIA" (2001) 18 Nat'l Insolv. Rev. 61.

Peoples, supro notie 1 at para. 43.

- Jeffrey G. Maclntosh. "The Role of Institutional and Retail Investors in Canadian Capital Markets" (1993) 31 Osgoode Hall L.J. 37I. See also Jeffrey G. Maclntosh. "Designing an Eflicient Fiduciary L.aw" (1993) 43 U.T.L.J. 425.

Altan C. Hutchinson. The Componies We Reep: Corporote Governance for a Democratic Socicty (Toronto: Irwin Law, 2005); H.J. Glasheck. "The Corporalte Social Responsibility Movement - The Latest in Maginot Lines to Save Capitalism" (1988) II Dal. L.J. 363; Stanley M. Beck. "The Corporation and Canadian Society" (Paper presented to the Conference on Canadian Corporate Governance, C.D. Howe Institute, 1994) [unpublisheci, manuseript on file with author].

" Glasbeek, ibid. at 46; Hutchinson. "A Not-So-Wise Decision," supra note 2. 
in Canadian popular culture, as is evidenced by the success of Joel Bakan's book, The Corporation, and the subsequent documentary by the same name. ${ }^{10}$

This article suggests that the response to Peoples and the Canadian corporate governance debate, as currently engaged, is operating on the false assumption that the principle-agent, shareholder primacy model accurately describes Canadian corporate law's treatment of public corporations." This article applies the Team Production Theory developed by American corporate law scholars, Margaret Blair and Lynn Stout, ${ }^{12}$ to argue that Canadian corporate law's understanding of public corporations that are not controlled by a single shareholder or group of shareholders, reflects a director primacy norm rather than a shareholder primacy norm. Canadian corporate law provides that directors of public corporations with widely-held share ownership and voting rights are free from direct control by any corporate stakeholders. ${ }^{13}$ Rent allocation among Canadian corporate stakeholders depends on extra-legal advantages. A potential departing point for Canadian corporate law, the oppression remedy, continues to develop to deal with such extra-legal advantages rooted primarily in unequal power relations among corporate stakeholders. However, in its current

Joel Bakan. The Corperutiom: The Pathological Parsuil of Profil and Power (Toronto: Viking Canada, 2004).

Mark Achbar, Jennifer Abbott \& Joel Bakan, The Corporation (Vancouver: Big Picture Media Corporation. 2004).

In fact. empirical studies reveal that the shareholder primacy norm has little or no actual impact on corporate decision-making. See D. Giordon Smith, "The Shareholder Primacy Norm" (1998) 23 J. Corp. L. 277.

1: Margarel M. Blair \& Lynn A. Stout, "A Team Production Theory of Corporate Law" (1999) 85 Va. L. Rev. 247 |TPT). Blair and Stout's theory has had signilicant impact in the American context. Sec, e.g.. "Symposium: Team Produclion in Business Organizations" (1999) 24 J. Corp. L. 743 (containing eight different articles on Team Production Theory); Eric A. Chiappinelli, "The Moral Basis of State Corporate Law Disclosure" (2000) 49 Cath. U.L. Rev. 697: and Mae Kuykendall, "Assessment and Evaluation: Retheorizing the Evolving Rules of Director Liability" (1999) 8 J.L. \& Pol'y 1. Given the significant scholarly attention Team Production Theory has received in the United States, it is surprising that it has not attracted greater allention in Canada. One notable exception is the debate between Robert Yalden and Jeffrey Maclntosh in the 2002 Queen's Business Law Symposium. This symposium did, however, pre-date Peoples, and the authors were more conecrned with questions of "what should be" than questions of "what is." Further, their focus was on questions surrounding the interplay between corporate and securitics law in Callatlia. See Robert Yalden. "Competing Theories of the Corporation and Their Role in Cannadian Business Law" in Anita I. Anand \& William F. Flanagan, eds., The Corporation in the 2lst Century: Papers Prevented at the 9th Queen's Ammal Business Law Symposium - 2002 (Kingston, Ont.: Queen's Annual Business Law Symposium, 2003) I and Jeflirey G. MeIntosh. "The End of Corporate Existence: Should Boards Act as Mediating Hicrarchs'? A Comment on Yalden" in Anand \& Flanagan, ibid, 37.

11 This is in contrast to corporations controlled by a single sharcholder or group of shareholders, where a stnall number of investors select and exercise tight control over the board and, at the same time, are often involved in managing the corporation as officers or direclors. The corporate law applicable to this type of corporation may more appropriately be explained by a principal-agent, shareholder primacy model, than by a mediating hicrarch model. It is notable that a majority of Canadian public corporations have been described as under legal or de facto control of a single or small group of shareholders. Recent Canadian scholarship has focused on this type of corporation. Sec, e.g., Ronald J. Daniels \& Paul Halpem, "Too Close for Comfort: The Role ol the Closely Held Public Corporation in the Canadian Leonomy and the Implications of Public Policy" (1996) 26 Can. Bus. L.J. II: Randall K. Morck. "On the Economics of Concentrated Ownership" (1996) 26 Can. Bus. L.J. 63 at 69; and Stephanie Ben-Ishai \& Poonam Puri, "Dual Class Shares in Canada: An llistorical Analysis" Dal. L.J. [fortheoming in 2006]. However, it still remains important to consider what Canadian corporate law has to say about public corporations that do not fit this model. These are the public corporations that are referred to in this article. 
and predicted future applications, the oppression remedy does not provide any given stakeholder group with an ability to dominate the boards of public corporations and obviate the director primacy norm.

Part II briefly describes Team Production Theory. Part III reviews Canadian corporate law as it applies to public corporations, assessing its consistency with the three concepts that have been identified as central to Team Production Theory:

1. Corporate personality and the derivative action;

2. The statutory fiduciary duty and duty of care; and

3. The limits on sharcholder voting. ${ }^{14}$

Concluding in Part III that the director primacy norm is at work in the parts of Canadian corporate law that are most comparable to American corporate law, Part IV argues that the judicial treatment of the oppression remedy is also consistent with a Team Production Theory of Canadian corporate law. Part V concludes by suggesting that because the director primacy norm accurately describes Canadian corporate law, further consideration needs to be given to corporate law's relative relevance in dictating how Canadian corporations currently operate. For example, do directors of Canadian corporations really think of themselves as "mediating hierarchs" and corporations as teams? More importantly, can directors of Canadian corporations play a mediating hierarch role given the current composition of corporate boards? The responses to these questions will help inform further inquiry into whether the director primacy norm is the ideal norm for Canadian corporate law.

\section{Team Production Theory}

Since Berle and Means suggested that the hallmark of the public corporation is the separation of ownership and control, ${ }^{15}$ numerous other institutional arrangements have developed to perform a similar function. These include both income trusts ${ }^{16}$ and partnerships. ${ }^{17}$ Accordingly, it is the board-based governance structure provided for in American (and Canadian) corporate law that differentiates public corporations from other business forms. ${ }^{18}$ On this basis, Blair and Stout have developed a descriptive and normative theory that challenges the dominant account that public corporations belong to sharcholders

TPT, supra note 12.

Adolf A. Berie, Jr. \& Gardiner C. Menns, The Modern Corporation and Private Propert! (New York: MacMillan, 1932).

For more on governance of income trusts, sce Michael J. Johnson. "Survival of the Fittest: The Corporate Governance of Income Trusts" in Poonam Puri \& Jeffrcy Larsen, eds.. Corporate Governance and Securities Regulation in the 21st Century (Markham, Ont.: LexisNexis Canada, 2004) 293.

17 See, e.g., Ontario's Limited Parmerships Aci. R.S.O. 1990. c. L.16. s. 13. Section 13 stalcs that: (1) A limited partner is not liable as a general partner unless, in addition to exereising rights and powers as a limited partner, the limited partner takes part in the control of the business: and (2) For the purposes of subsection (1), a limited partner shall not be presumed to be taking pan in the control of the husiness by reason only that the limited partner exercises rights and powers in addition to the rights and powers conferred upon the limited partner by this Act. For more on limited liability partnerships, see J. Anthony VanDuzer, The Law of P'armerships and Corporations, $2 \mathrm{~d}$ ed. (Toronto: Irwin Law. 2003) c. 2.

Franklin A. Gevurtz. "The European Origins and the Spread of the Corporate Board of Directors" (2004) 33 Stetson L. Rev. 925. Gevurtz. demonstrates that around the world the key similarity among corporate governance regimes is that corporations are managed by, or are under the direction of, a board of directors. 
and that directors are shareholders' agents. Unlike others who have critiqued the shareholder primacy understanding of corporate law, Blair and Stout conceive of public corporations as a nexus of contracts. ${ }^{19}$ That is, like those who support the shareholder primacy norm, they argue that corporations consist of bargains made between various corporate stakeholders, even though not all such bargains are necessarily spelled out in complete contracts.

Blair and Stout's theory, referred to as a Team Production Theory, suggests that directors of public corporations, as prescribed by American corporate law, are "mediating hicrarchs" who are accountable to no particular corporate stakeholder. ${ }^{20}$ The current state of the law of public corporations with respect to these mediating hierarchs in the United States is supported by the team production concept from economic literature. ${ }^{21}$ Public corporations are comprised of team members, such as shareholders, creditors, workers, managers, and communities that form a team (the corporation) because the members recognize that each will obtain more from a collective enterprise than on their own. ${ }^{22}$ On this basis, all of the team members make investments that are specific to the team. Team members expect to share in the corporation's production rents and surpluses, but are unable to contract completely for that result, due to reasons of cost, incentives, and uncertainty as to the separate value of their contributions following team production. ${ }^{3}$

Blair and Stout review the various possibilities, other than the use of a mediating hierarch, for allocation of rents and surpluses $e x$ ante and ex post among team members, and conclude that they produce sub-optimal outcomes. ${ }^{24}$ For example, if an individual team member was to be trusted with making decisions on allocation of rents and surpluses ex post, each decision they made would be treated as suspicious. Accordingly, adopting Rajan and Zingales' idea of vesting allocational authority in an independent third party, ${ }^{25}$ Blair and Stout suggest that the team delegates to the board of directors the ultimate authority over running the corporation, and also the distribution among team members of production rents

14 TPT, supra note 12 at 287. For a discussion of other conceptions of corporations (for instance, as an economic institution for social service), see E. Merrick Dodd. Jr., "For Whom Are Comorate Managers Trustete?" (1932) 45 Har. L. Rev. 1145 at 1148 . See also, Ruth O. Kuras, "Corporate Social Responsibility: A Canada-U.S. Comparative Analysis“" (2002) 28 Man. L.J. 303 at 304-305. TPT, ibid. at 282

$\because \quad$ bid. at 272. Team production refers to the division of labour used when complex forms of production cannot be accomplished efliciently (or at alt) by individuals or families. Firms coordinate team production to (a) reduce transaction costs, and (b) exploit economies of scale or scope. This theory can be traced in large part to Ronald Coase: see R.H. Coase, The Firm, the Markel, and he Law (Chicago: University of Chicago Press, 1988). See also Armen A. Alchian \& Harold Demsetz, "Production, Information Costs, and Economic Organization" (1972) 62 Amcrican Economics Revicw 777 and Michael C. Jensen \& Wiltiam H. Meckling, "Theory of the Firm: Managerial Behavior, Agency Costs and Ownership Structure" (1976) 3 Journal of Financial Economics 305 . A complete discussion of the economic literature that the Team Production Theory depends on is beyond the scope of'this article. The key insight is that the economic justification for the corporation is that a corporation will form when it is more clficient for people to work together within a corporation as compared with simply relying upon individually negotialed eontracts.

$\therefore \quad$ TPT, ibid. at 277.

$\therefore$ Ihid.

: $\quad$ bid. at 269-71.

3s Raghuram G. Rajan \& Luigi Zingales, "Power in a Theory of the Firm" (1998) I13 The Quarterly Joumal of Economics 387 at 392. 
and surpluses. ${ }^{26}$ The result is that the costs of obtaining team-specific investments are lowered, and employing this mediating hierarch model of governance maximizes social wealth. Because of the existence of a mediating hierarch, public corporations can make credible commitments that they will refrain from opportunistic behaviour directed at members of the team. Blair and Stout recognize that this is only a second-best solution to the team production problem, because the independent board has no direct stake in the success of the corporation. However, the mediating hierarch solution is superior to alternative rent and surplus allocation mechanisms they canvas.

Blair and Stout claim that the current state of American corporate law reflects Team Production Theory's understanding of the role of the board. ${ }^{27}$ The procedural hurdles and substantive limitations on the use of the derivative action to enforce directors' duties, as well as the limited ability of shareholding voting rights to impact on director preferences, give directors broad discretion to manage the corporation without pure devotion to any particular team member's interests. ${ }^{2 k}$ In reviewing Blair and Stout's description of American corporate law, David Millon has suggested that a more accurate statement is that:

[T]hough corporate law pays lip service to shareholder primacy, it is actually inelfective when it comes to rendering management accountable to shareholders. This doctrinal ineflicacy ... reflects a conmmitment to director discretion, which in this roundabout manner constitutes the board as independent ... mediators. ${ }^{29}$

As the next Part suggests, such a reflection is equally applicable in the Canadian context.

\section{II. Team Production Tileory and Canadian Corporate LaW}

The Canadian Business Corporations $A c r^{30}$ provides an example of the type of legal rules that public corporations must adhere to in Canada. ${ }^{31}$ This Part reviews the extent to which the judicial application of three central features of Canadian corporate law found in the $C B C A$ fit with the role ascribed to directors by Team Production Theory and depart from the

so TPT, supra note 12 al 272-76.

27 ibid.

$28 \quad$ bid. it $287-315$.

29 David Millon, "New Game Plan or Business us Usual"? A Critique of the l'eam I'roduction Model of Corporate Law" (2000) 86 Va. L. Rev. 1001 at 1021 . In addition to Millon, a number of other commentators have critiqued the Team Production Model of corporate law. Like Millon, other commentators have focused primarily on Blair and Stout's position that the Team Production Model of corporate law is the ideal model for all team members. In particular, the tenuous position of employees is oflen pointed to. See, e.g., Kent Greenficld. "The Place of Workers in Corporale Law" (1998) 39 B.C.L. Rev. 283; Lawrence E. Mitchcll. "Structural Holes. CEOs, and Informational Monopolies: The Missing Link In Corporate Govemance" (2005) 70 Brook. L. Rev. 1313; and Kellye Y. Testy. "Linking Progressive Corporate Law with Progressive Social Movements" (2002) 76 Tul. L. Rev. 1227. For an example of the other forms of critique that the Team Production Model of corporale law has been subject to, sec John C. Coatus IV. "Measuring the Domain of Mediating Hicrarchy: How Contestable arc U.S. Public Corporations?" (1999) 24 J. Com. L. 8.37 at 850-51. For example, Blair and Sloul have been criticized for focusing on shareholder voting rights because they overlook the market for corporate control.

30 R.S.C. 1985, c. C-44 [CBCA].

31 For a review of the differences in the provincial corporate statutes, see Ronald J. Danicls, "Should Provinces Compele? The Case for a Competitive Corporate Law Market” (1991) 36 McGill L.J. 130. 
shareholder primacy understanding of Canadian corporate law that retains its hegemony in Canadian corporate governance debates.

Inherent to the concept of agency is that the principal enjoys control or power over the actions of the agent. ${ }^{32}$ The role of directors as set out in Canadian corporate law departs from this understanding. The primary legal role of directors is to "manage, or supervise the management of, the business and affairs of a corporation." ${ }^{\text {"33 }}$ Canadian corporate law does not grant sharcholders any power to initiate action or to control the board. A review of the derivative action, the statutory duties of boards, and shareholder voting reveals that directors are not constituted as shareholders' agents by Canadian corporate law. Rather, these three central aspects of Canadian corporate law allow boards to pursue the mediating hierarch model envisioned by Team Production Theory.

\section{A. CORPorate Personality AND the Derivative ACtion}

The corporation's status as a legal person, separate from its shareholders, has been described as a striking aspect of corporate law supporting the mediating hierarch model. ${ }^{34}$ Derived from the legal fiction of corporate personality is the concept in Canadian corporate law that can be traced back to Foss $v$. Harbonte ${ }^{35}$ that only a corporation can sue for injuries to the corporation, regardless of any injury to corporate stakeholders. Following Foss $v$. Harbottle, corporate stakeholders, including shareholders, could not sue for an injury to the corporation at common law. ${ }^{36}$ Foss $v$. Harbottle was based on the position that if a corporation is a legal person, separate from its members, and the corporation was wronged, the corporation itself should sue. ${ }^{37}$ The rule in Foss $v$. Harboulle is particularly problematic with respect to fiduciary duties. Directors owe fiduciary duties to the corporation. According to the rule in Foss v. Harbollle, any action for breach of fiduciary duty must be brought by the corporation. However, in public corporations the corporation acts through the board, causing a conflict where the board is asked to bring a claim in the corporation's name against themselves. It is this problem that is the source of the derivative action in Canadian corporate law, which permits certain corporate stakeholders, under limited circumstances, to step into the shoes of the corporate entity and sue in its name and on its behalf.

The $C B C A$ provides that, in order for leave to be granted for a derivative action, the complainant must show that: not less than 14 days notice has been given to the directors of the corporation of the intention to apply to the court if the directors do not bring or defend the action, unless otherwise ordered by the court; the complainant is acting in good faith; and that it appears to be in the interests of the corporation or its subsidiaries that the action be

VanDuzer, supra note 17, c. 5. CBCA, supra note 30, s. 102(1).

TPT, stupra nole 12 at 290-315.

(1843), 2 I lare 461; 67 E.R. 189. Fur a comprehensive treatment of the history of the oppression remedy, sec Jelfrey G. Maclntosh, "Minority Shareholder Rights in Canada and Eingland: 1860-1987" (1989) 27 Osgoode Hall L.J. 561 and Deborah A. DeMott, "Oppressed but Not Betrayed: A Comparative Assessmetnt ol "Canadian Remedies for Minority Shareholders and Other Corporale Constituents" (1993) 56:I Law \& Contemp. Probs. 181.

DeMolt, ibid. at 192.

Jason W. Neyers, "Canadian Corporate Law, Veil-Piercing. and the Private Law Model Corporation" (2000) 50 U.T.L.J. 173 at 187. 
brought, prosecuted, defended, or discontinued. ${ }^{3 k}$ To bring a derivative action under the $C B C A$, the applicant must be a "complainant." $\mathrm{A}$ "complainant" includes:

(a) a registered holder or beneficial owner, and a former registered holder or beneficial owner, of a security of a corporation or any of its afliliates;

(b) a director or an ollicer br a former director or officer of a corporation or any of its affiliates:

(c) the Director; or

(d) any other person who, in the discretion of a court, is a proper persen to make an application under this Part. $^{39}$

For the most part, the procedural aspects of the derivative action found in Canadian corporate law mirror the American requirements. These procedural aspects of the derivative action have been used by Blair and Stout to support the claim that the director primacy norm exists in American corporate law on three grounds: (a) the procedural aspects of the derivative action limit its use; (b) if a derivative action is successful any damages go to the corporation; and (c) under certain circumstances, stakeholders other than shareholders are granted standing to sue derivatively. ${ }^{+1}$ All three propositions are supported by Canadian corporate law."1

A review of Canadian case law from I November 1999 to 1 November 2004, reveals that only three derivative actions were reported." A shareholder initiated each of these actions and only one was successful. None of the actions were in the context of a public corporation. This review of the case law confirms Blair and Stout's observation in the Canadian context that the derivative action has been utilized effectively in limited situations. ${ }^{43}$

$C B C A$, supra nole 30, s. $239(2)$.

Ibid., ss. 238. 241.

TPT, supra note 12 at $294-97$.

McAteer v. Detroncraff Developments Lid, 2001 ABQB 917, 301 A.R. 1 [McAleer]; Discovery Enterprives Inc. :. Ehco Industries Lid., 2002 BCSC 1236. [2(1)2] B.C.J. No. 1957 (QL) [Discovery Enterprises]; Jordan Inc. v. Jordan Engineering Inc: (2004), 48 B.L.R. (3d) 115 (Ont. Sup. CI. J.) [Jordan Inc:]

A Quicklaw search lor "derivative $/ 2$ action" and "duly" in the CJ database revealed 83 cases. Out of these cases only the highest court decision for each ease was considered and only the main action was considered. The small number of reported decisions may also be explained, in part, by the fact that cases are settled out of court. However, currently there is no published empirical evidence to suggest that there are a significant number of such cases. In McAteer, ibid., although there were other actions, the derivative action on behalf of Devoncroft was based on allegations that Billes and McAteer, as directors and officers of DDL, breached their contractual, legal, and liduciary duties to the corporation to act honestly, in good faith, and in the best interests of Devoncroft: failed to comply with the provisions of the unanimous sharcholder agreement; and failed to manage the aflairs of the corporation prudently, and thereby protect its interests. The derivative action failed as Rooke J. held that the decisions made by the direclors of the corporation were properly considered. In Discovery Enterprises, ibid., Discovery Enterprises, as a shareholder of Ebco Industries Lid., iniliated a derivative action based on misuse of corporate funds. The derivative action was dismissed. In Jordan / $\mathrm{mc}$. ibid. one of the shareholders and principals of Jordan Inc. brought a derivative action on the basis of wrongful appropriation by the other principal and sharetolder through Jordan Engineering Inc., which was a breach of her fiduciary duty to the corporation. The action was successful as Kruzick J. hold that Murre took advantage of a business opportunity that was not in the best interest of Jordan Inc.

TPT, supra note 12 at 294-97. 
As laccobucci and Davis have noted, in the Canadian context, the real danger is not a multiplicity of derivative actions, but a complete absence of suits. ${ }^{\text {Hh }}$ Just as in the American context, this result can be explained in the Canadian context, in part, by the procedural requirement for bringing a derivative action. Blair and Stout's observation regarding the recipient of damages in a successful derivative action is also accurate in the Canadian context. ${ }^{45}$ The fact that the corporation is the recipient of any damages awarded ensures that any benefits from such an action have the potential to accrue to all of the corporation's stakeholders. Shareholders can only benefit directly when the board determines that at dividend should be made to shareholders. Another signilicant feature that supports the notion that the derivative action exists for the benefit of the entire corporation is that the $C B C A$ expressly provides that evidence of shareholder approval, or the possibility of future shareholder approval, is not determinative of whether a derivative action may proceed. ${ }^{36}$ The procedural hurdles to suing derivatively, the limited weight of shareholder approval, and the fact that damages are awarded to the corporation can be justified by the mediating hierarch model because these factors insulate directors from shareholder (and other corporate stakcholder) challenge and control.

While the derivative action has been utilized only by sharcholders in Canada, and only in rare cases where they have been able to overcome the collective action and procedural hurdles, there is a broader scope for the range of complainants that can bring a derivative action. ${ }^{47}$ Out of this range of complainants, however, only creditors have successfully sought standing to sue derivatively. In Dylex Lid. (Trustee of) $v$. Anderson, ${ }^{48}$ the Ontario Superior Court of Justice held that the trustee in bankruptcy as representative of creditors of Dylex was an appropriate complainant for a derivative action. Four months after the completion of an agreement between Dylex and the Hare of Wolf Group Inc., which provided for the latter to acquire all of the shares of Dylex, Dylex was put into bankrupicy. The trustee claimed that the agreement breached the directors' duty of care to Dylex creditors and fiduciary duty to Dylex.

The limited use of the derivative action is consistent with Team Production Theory, which seeks to limit rent seeking by corporate stakeholders than wider availability of the action would provide. However, corporate stakeholders need to be granted the ability to sue directors derivatively in order for the existence of the derivative action to continue to have any role in ensuring that team members can trust the board. The explanation for why shareholders have been able to use the remedy, albeit on rare occasions, may be that in those instances they have been able convince the court that they have interests that are in harmony with a number of other stakeholders. However, where the corporation approaches insolvency, this might not be the case. In such situations, shareholders may prefer high-risk approaches, with low downside risk to them, but at the expense of other corporate stakeholders, such as creditors and employees. Accordingly, the most appropriate method to ensure that boards

Ldward M. Jaccobucci \& Kevin E. Davis, "Reconciling Derivative Claims and the Oppression Remedy" (2000) 12 Sup. C1. L. Rev. (2d) 87.

". William Kaplan \& Bruce Elwood, "The Derivative Action: $A$ Sharcholder's 'Bleak House"?." (2003) 36 U.B.C. L. Rev. 443 at 455 .

CBCA, supra note 30, s. 242(1).

VanDuzer, stupra note 17, c. 9.

(2003). 63 O.R. (3d) 659 (Sup. Ct. J.) [Dyter]. 
continue to exercise their mediating hierarch role for the best interests of the corporation as a whole is to grant creditors standing to sue derivatively in such instances. On this basis, Dylex is consistent with the pattern in Canadian corporate law that supports granting standing to suc derivatively only in limited circumstances to protect the interests of the corporation as an entity, not the interests of any particular group of corporate stakeholders.

\section{B. Statutory Duties}

Moving from the procedure of bringing a derivative action to the substance of directors' duties, upon which corporate stakeholders may base a derivative action to sue in the corporation's name if breached, Blair and Stout claim that it becomes clear that such duties serve the corporation rather than any particular corporate stakeholder. In the Canadian context, the judicial application of both the statutory fiduciary duty and the statutory duty of care support Blair and Stout's claim. That is, both duties will subject directors to liability only in situations where the conduct harms the corporation as a whole, not just the corporation's shareholders.

\section{Fiduciary DUTY}

The $C B C A$ statutory duty referred to by Canadian commentators as the "fiduciary duty" and by American commentators as the "duty of loyalty," requires directors to "act honestly and in good faith with a view to the best interests of the corporation." Canadian commentators have described the fiduciary duty in broad terms:

In general terms. the fiduciary obligations of directors include (a) a duty to act in the best interests of the corporation and, correspondingly, not wo do anything that undermines or thwarts those best interests; (b) a duty not to compete with the corporation, including a prohibition against appropriating its business opportunities and assets; (c) a duty to maintain the conlidentiality of information received or knowledge obtained through the fiduciary position, including a prohibitiun against making use of such confidential information for the director's or officer's personal benefit. ${ }^{\text {st) }}$

The application of this broad duty, however, has generally been restricted to a narrow range of situations where a director has made some profit or received some advantage at the expense of the corporation. ${ }^{\text {s1 }}$ Such situations may arise where a director competes with the corporation, is involved in a transaction with the corporation in the director's personal capacity, or where he or she takes advantage of opportunities personally that they had a duty to obtain for the corporation. Some carly case law, and at least one commentator, have suggested that the fiduciary duty should extend to situations where directors have made profits as a result of their position, but not at the corporation's expense. ${ }^{52}$ However, in Peoples the Supreme Court noted that the Wise brothers did not stand to realize a direct gain at the expense of the corporation in adopting the inventory procurement policy, and held that 
"it is not required that directors and officers in all cases avoid personal gain as a direct or indirect result of their honest and good faith supervision or management of the corporation."'33 The Court pointed to director's compensation and the possibility of the dual position as shareholder and director as examples of situations where directors' interests will "innocently and genuinely coincide with those of the corporation."

The two situations where the Canadian fiduciary duty has received the most judicial attention are in the takeover context and the bankruptcy and reorganization context. These situations are not outliers; rather, they represent circumstances where the tension between various stakeholders' individual interests and the interests of the corporation as a whole are the most visible.

With respect to the takeover context, in response to an offer to purchase a controlling interest in a corporation at a premium price, directors of the corporation may take actions $\mathrm{s}^{55}$ to defeat the offer, which normally includes the replacement of directors. Takeovers generally benefit both shareholders who sell and those who retain their shares. Those who sell, enjoy a premium. Those who retain their shares enjoy the improvements that the bidder plans to make. However, takeovers may harm employees, suppliers, the environment, local communities, and others who have made corporation specific investments. For example, the bidder may downsize, move plants, and replace employees. Accordingly, if directors take actions to defeat a takeover, this will generally be at the expense of shareholders and may be to the benefit of other corporate stakeholders. The fact that Canadian courts have generally not intervened when directors have taken such defensive measures and considered such actions to be a breach of fiduciary duty runs counter to the shareholder primacy norm and supports the director primacy norm.

In Teck Corp. Lid. v. Millar, ${ }^{56}$ Berger J. held that directors must be able to act in the best interests of the corporation in responding to a takeover bid, and that this extends beyond shareholders' interests:

A classical theory that once was unchallengeable must yield to the facts of modern life. In fact, of course, it has. If today the directors of a company were to consider the interests of its employees no one would argue that in doing so they were not acting bonafick in the interests of the company itself. Similarly, if the directors were to consider the consequenecs to the community of any policy that the company intended to pursue, and were deflected in their commitment to that policy as a result, it could not be said that they had not considered bona fide the interests of the shareholders.

I appreciate that it would be a breach of their duty for directors to disregard entirely the interests of a company's shareholders in order to confer a benelit on its employees: Parke v. Daily Nenv Ltd., [1962] Ch. 927. But if they observe a decent respect for other interests lying beyond those of the company's shareholders

Peoples, supra note I at para. 39.

thid.

For example, a poison pill may be put into place. See Jelfirey G. Maclntosh, "The Poison Pill: $A$ Noxious Nostrum for Canadian Sharcholders" (1989) 15 Can. Bus. L.J. 276 and Peter Dey \& Robert Yalden. "Keeping the Playing Field Level: Poison Pills and Directors' Fiduciary Duties in Canadian Take-Over Law" (1990) 17 Can. Bus. L.J. 252.

(1972), 33 D.L.R. (3d) 288 (B.C.S.C.) [Teck Corp.]. 
in the strict sense, that will not, in my view, leave directors open to the charge that they have failed in their fiduciary duty to the company. ${ }^{57}$

In faimess to proponents of the conventional principal-agent interpretation of Canadian corporate law, it is important to note that the facts in Teck Corp. did not involve a conflict between the interests of shareholders and another group of stakeholders. Rather, what was at issue in Teck Corp. was the competing interests of two parties attempting to acquire control of Afton Mines Ltd. and Afton's board's conduct in relation to the losing party. ${ }^{5 \mathrm{M}}$ Accordingly, Berger J.'s dide finition of the best interests of the corporation was obiter in Teck Corp. ${ }^{59}$ Further, prior to Peoples, Berger J.'s conception of the best interests of the corporation had not been endorsed in any subsequent decisions. ${ }^{610}$ Equally notable is that the Parke decision, referred to in Teck Corp., concerned a set of facts where employees' interests were in direct competition with sharcholders' interests. ${ }^{61}$ However, prior to Peoples, Parke had only been followed in one subsequent Canadian decision and the case involved a cooperative, not a corporation. ${ }^{62}$

Prior to Peoples there was a measure of ambiguity on the state of Canadian corporate law relating to the statutory fiduciary duty. However, the current state of Canadian corporate law on the statutory fiduciary duty is squarely consistent with Team Production Theory. In Peoples, the Supreme Court of Canada applied the reasoning developed earlier to the bankruptcy and reorganization context, holding that "in determining whether they are acting with a view to the best interests of a corporation it may be legitimate, given all the circumstances of a given case, for the board of directors to consider, inter alia, the interests of shareholders, employees, suppliers, creditors, consumers, governments and the environment." ${ }^{63}$ The Supreme Court noted that, "creditors' interests increase in relevancy as a corporation's finances' deteriorate." ${ }^{\text {"th }}$ However, the Court also recognized that there are other stakeholders that must be taken into account in an insolvency situation and held that "the Canadian legal landscape with respect to stakeholders is unique. Creditors are only one set of stakeholders." ${ }^{\text {"Os }}$ On this basis, the Court concluded that because the adoption of the inventory procurement policy did not harm the corporation as a whole (defined more broadly than certain creditors or other stakeholders), the Wise brothers had not breached their fiduciary duty.

Prior to the Supreme Court of Canada's decision in Peoples, both the Quebec Superior Court and the Ontario Superior Court of Justice indicated that the law in Canada appeared to be moving toward imposing a fiduciary duty on directors of a corporation. ${ }^{\text {st }}$ In the Quebec Superior Court decision, Greenberg J., held that since only creditors have a meaningful stake

Ibid. at 314, cited with approval in Peoples, stipra note 1 at para. 42.

See Lee, supra note 2 at $213-14$.

lbid.

Ihid.

lbid. at 215-16.

Ibid.

Peoples, supra note 1 al para. 42.

Jbid. at para. 49.

Ihid. at para. 48.

People's Deparment Lad. (1992) Inc.. Re. (1998), 23 C.B.R. (4th) 200 (Qc. Sup. C1.) [Peoples 1998): Canbook Distribution Corp. 1. Burins (1999), 45 O.R. (3d) 565 (Sup. CI. J.). 
in the assets of an insolvent corporation, directors have an obligation to ensure that the corporation is properly administered and that its assets are not dissipated in a manner that is prejudicial to its creditors..$^{67}$ Justice Greenberg adopted Professor Ziegel's view on extending fiduciary duties to creditors, holding that " $[i] t$ is not unreasonable, in exchange for the benefit of limited liability, to impose a duty on directors not to sacrifice creditors' interests when the going gets rough.... If the company is insolvent ... only the creditors still have a meaningful stake in its assets." ${ }^{\circ 6}$ The Supreme Court rejected this line of reasoning and held that the general nature of the statutory fiduciary duty does not change when the corporation approaches insolvency or finds itself in bankruptcy. In doing so, the Court upheld directors' legally mandated mediating hicrarch role in the bankruptcy and reorganization context.

The only application of Peoples by an appellate court at the time of writing also supports a Team Production Theory explanation of the judicial application of the Canadian fiduciary duty. In Re Stelco Inc., ${ }^{69}$ as part of Stelco's reorganization under the Companies 'Creditors Arrangemen $A c t,{ }^{70}$ Farley J. applied the reasoning in Peoples to void the appointment of two Stelco directors, Roland Keiper and Michael Woollcombe, pursuant to s. 111(1) of the $C B C A$. " In reaching his decision, Farley J. characterized Stelco's goal as its successful emergence from $C C A A$ proceedings, as a long-term, viable, and competitive participant in the domestic and international steel industry, with the maximum benefit for the stakeholders on a collective basis through the facility of a "better corporation." stakeholders of Stelco had brought a motion arguing that, because Mr. Keiper and Mr. Woollcombe were shareholder representatives, as board members they would favour maximizing shareholder value at the expense of the interests of the employees.

Mr. Keiper was the President of Clearwater Capital Management Inc., a Toronto-based investment manager. Prior to co-founding Clearwater in 1999, Mr. Keiper headed the Canadian proprietary investing activities of RBC Dominion Securities. Mr. Woollcombe was a principal of VC \& Co. Incorporated, which acts as a strategic advisor to institutional and other shareholders with respect to their investments in Canadian public and private companies. Justice Farley agreed with the employee stakeholders, holding that after two days of serving on the board, Mr. Keiper and Mr. Woollcombe were not in a position to serve as

Peoples 1998, ibid. A number of Canadian academics have commented on this decision. See David Thomson, "Directors. Creditors and Insolvency: A Fiduciary Duty or a Duty Nol to Oppress?" (2000) 58 U.T. Fac. L. Rev. 31; Janis P. Sarra \& Ronald B. Davis, Director and Officer Liabilin in Corporate Insolvency (Markham. Ont.: Butterworths Canada, 2002) at 15-21; C. Graham W. King, "Extending Fiduciary Principles to the Director-Creditor Relationship: A Canadian Perspective"(2002) 29 Man. L.J. 243; Edward M. laccobucei, "A Wise Decision? An Analysis of the Relationship between Corporate Ownership Structure and Directors" and Ofticers' Duties" (2002) 36 Can. Bus. L.J. 337; Christopher C. Nicholls, "Liability of Corporate Offieers and Directors to Third Parties" (2001) 35 Can. Bus. L.J. 1 at 30-37; and Andrew Keay, "The Director's Duty to Take into Account the Interests of Company Crediturs: When is it Triggered?" (2001) 25 Melboume U.L. Rev. 315. (2005). 7 C.B.R. (5th) 310 (Ont. Sup. Ct. J.) [.Steico].

R.S.C. 1985 , c. C-36 [CCAA]].

Section $111(1)$ of the $C B C A$, supra note 30, provides that: "Despite subsection $114(3)$, but subject to subsections (3) and (4), a quorum of directors may till a vacancy among the directors, except a vacancy resulting from an increase in the number or the minimum or maximum number of directors or a failure to elect the number or minimum number of directors provided for in the articles." 
neutral intermediaries, a corporate law requirement of board members of public corporations. Justice Farley found that Mr. Keiper and Mr. Woollcombe were "spokespersons for the shareholders" ${ }^{73}$ and had, as their goals, short-term maximization of shareholder value. Justice Farley did not feel that the two directors were neutral or that they would "do the right thing in using their business judgment, not the thing which they know or even suspect that any outsider (individual or supposedly important and possibly powerful stakcholder or partial group thereof) may wish to have happen for that outsider's benclit, not the benefit of the new better corporation."74

Justice Farley's decision represents a departure from a Team Production Theory of Canadian corporate law. It runs counter to Canadian courts' historical reluctance to interfere with directors' independence. Justice Farley cites the reasoning in Peoples to enable one group of stakeholders, employees, to obviate the independence of the Stelco directors on the basis of a perception that two directors would perform their role with a view to short-term shareholder value maximization, rather than with a view to the best interests of the corporation. Justice Farley's decision challenges Canadian corporate law's understanding of the director as a mediating hierarch based on the reality that directors of public companies in Canada generally havd interests that align with a particular group of shareholders or other powerful stakeholders.

On appeal, Blair J.A. rejected Farley J.'s attempt to depart from a Team Production Theory understanding of the legal role of directors to consider who was actually playing this role. ${ }^{75}$ Justice Blair used the reasoning in Peoples to uphold the independent legal role of directors and Canadian courts' reluctance to interfere with that role and propel into the shoes of the board absent clear evidence that the directors were pursuing their interests ahead of the corporation's interests. ${ }^{\text {it }}$ Justice Blair accepted as a reality that there are connections between Canadian corporate directors and various stakeholders, but held that this in itself was not sufficient to justify a finding of a breach of fiduciary duty and the imposition of a corrective sanction. ${ }^{\eta 7}$ Accordingly, Blair J.A. reinstated Mr. Keiper and Mr. Woollcombe.

\title{
2. DUTY OF CARE
}

In addition to the statitory fiduciary duty, Canadian directors have a legal obligation to "exercise the care, diligence and skill that a reasonably prudent person would exercise in comparable circumstances." $"$ On its face, the statutory duty of care appears to be broader than the statutory fiduciary duty. Unlike the fiduciary duty, which stipulates the identity of the beneficiary of that duty as the corporation, the duty of care leaves the beneficiary of the duty open. Accordingly, in Peoples, the Court held that such a duty could be owed to creditors. However, in practice, the application of the statutory duty of care has been

\author{
Ibid. at para. 20. \\ lbid. at para. 4. \\ Steko Iitc., Re (2005). 75 O.R. (3d) 5 (C.A.). \\ Ibid. at para. 60 . \\ Ihid. at para. 76. \\ CBCA, supra note 30, s. $122(1)(b)$.
}


extremely limited by the business judgment rule..$^{79}$ In applying the business judgment rule to the inventory procurement policy that the Wise brothers had adopted, and holding that the Wise brothers had not breached their duty of care, the Supreme Court described the Canadian business judgment rule as in line with its commonwealth counterparts:

Canadian courts, like their counterparts in the United States, the United Kingdom, Australia and New Zealand. have tended to take an approach with respect to the enforcement of the duty of care that respects the fact that directors and officers often have business expertise that courts do not. Many decisions made in the course of business, allhough ultimately unsuccessful, are reasonable and defensible at the time they are made. Business decisions must sometimes be made, with high stakes and under considerable time pressure. in circumstances in which detailed information is not available. It might be tempting for some to see unsuccessful business decisions as unreasonable or imprudent in light of information that becomes available ex post facto. Because of this risk of hindsight bias, Canadian courts have developed a rule of deference to business decisions called the "business judgment rule", adopting the American name for the rule."

The use of the business judgment rule to limit the application of the duty of care runs counter to the shareholder primacy model as it insulates directors from claims by corporate stakeholders, including shareholders. The limiting of breach of duty of care actions to those instances where the corporation's interests as a whole have not been served, supports the mediating hierarch model as it prevents corporate stakeholders from using lawsuits to extract rents from the corporation. Consistent with the theory articulated by Blair and Stout, the limiting role of the business judgment rule in the Canadian context allows directors to sacrifice shareholders' interests for those of other corporate stakeholders, since it "'ties the hands' of shareholders in public corporations in a fashion that ultimately serves their interests as a class, as well as those of the other members of the corporate coalition."

\section{THE Limits ON SHaReholder Voting}

The third proposition that Blair and Stout put forward to support the idea that the director primacy norm is at work in American corporate law is based on the limits of shareholder voting. The practical and legal obstacles in American corporate law ensure that shareholders cannot use such voting rights to exercise authority over the board of directors. Accordingly, directors can perform their mediating hierarch role free from the direct control of shareholders or any other stakeholder of the public corporation. The legal and practical obstacles to sharcholder action in the Canadian context have been observed by a number of commentators who have argued for greater shareholder voice. ${ }^{.2}$

For an alternative view concerning the role of the business judgment rule following Peoples, set Rousseau, supra note 2. Rousseau references the Supreme Court's reliance on ant. 1457 of the Civil Code of Quebec (C.C.Q.) and argues on this basis that the conception of the duty of care in Peoples may lead to a greater role for the judiciary in corporate governance and grealer liability risk for directors. Peoples, supra note 1 at para. 64.

TPT, supra note 12 at 305.

": Sec, e.g., Janis Sarra. "The Corporation as a Symphony: Are Shareholders First Violin or Second Fiddle?" (2003) 36 U.B.C. L. Rev. 403. See also Janis Sarra, "Convergence Versus Divergence, Global Corporate Governance al the Crossroads: Governance Norms, Capital Markets \& OECD Principles for Corporate Governance" (2001-2002) 33 Ottawa L. Rev. 177; Edward M. lacobucei, "The Effects of Disclosure on Exceulive Compensation" (1998) 48 U.T.L.J.489; and Anita Indira Anand, "Shareholder Isolation and the Regulation of Auditors" (2004) 54 U.T.L.J. I. 
Before outlining the obstacles to shareholder action in the Canadian context, it is important to address the American critique of Blair and Stout's focus on shareholder voting rights. Blair and Stout have been criticized for focusing on shareholder voting rights because they overlook the market for corporate control, which turns "the limited de jure shareholder voice into a powerful de facto form of shareholder control." ${ }^{.33}$ While observations concerning market-based accountability measures are important in evaluating the relative importance of law, they are beyond the scope of the current project of considering the salience of Blair and Stout's description of the legal role of directors of Canadian corporations. As part of this evaluation, a range of market forces that may cause directors to be accountable to shareholders are not considered - including, for example, capital and reputational markets. Where Canadian corporate law does address these forces in the context of the market for control, the earlier discussion on the statutory fiduciary duty indicates that directors' mediating hierarch role is upheld.

Shareholders of Canadian public corporations have the right to vote in relation to electing or removing directors and also in relation to certain "fundamental" corporate changes. ${ }^{\$-t}$ However, the right to vote has significant free rider, collective action, and rational apathy problems associated with it. With respect to electing the board, management will generally set the date for elections, nominate candidates, and use corporate funds to solicit proxy votes from shareholders. While shareholders who disagree with management's proposals for a board may obtain a list of shareholders, the shares they hold, and their addresses from the corporation so as to contact other shareholders for the purpose of influencing their voting. such action is rare. ${ }^{\$ 5}$ This is in part because, if a shareholder does solicit proxies, other than through a "public broadcast," from more than 16 shareholders," they must engage in the costly process of sending out a dissident's proxy circular. ${ }^{x \text { " }}$

Similarly, a shareholder's right to vote on "fundamental" changes is also limited in reality. The types of changes that are defined as "fundamental" are narrow. They include amendment of articles; ${ }^{88}$ amendment, repeal, or the introduction of new by-laws; ${ }^{84}$ amalgamation; ${ }^{90}$ and sale of substantially all the corporation's assets." In each case, without a shareholder proposal, all shareholders can do is agree or disagree with the question put to them by the directors.

The exception to the general rule that the board sets the agenda for shareholder meetings, and that the right to vote on fundamental changes is nothing more than a veto power, is the statutory provision for shareholder proposals. Shareholders who have a right to vote, who have held shares for at least six months, and who hold either I percent of the total outstanding voting shares of the corporation or shares with a fair market value of $\$ 2000$, may

Coates, supra note 29 at $850-51$.

CBCA, supro note 30, ss. 140, 146, 173 and 176.

Mbid., ss. 21(3), (9).

Ibid.; Canadian Bussiness Corporations Regulations, S.O.R./2001-512, s, 67 [CBCR].

CBCA, ibid., s. 150(1)(b): CBCR, ibid., ss. 61-64.

$C B C A$, ibid., s. 135(6).

Ibid., s. 103.

Ibid., s. 183(1).

lbid., ss. $189(3)-(9)$. 
make a shareholder proposal for any matter they wish to discuss, including amendments to the corporation's articles. ${ }^{92}$ The proposal may include nominations for the election of directors only if holders of not less than 5 percent of the shares entitled to vote sign the proposal. If the corporation is required to distribute a management proxy circular, the shareholder proposal must be included along with a statement by the shareholder; however, the total word count cannot exceed 500 words. ${ }^{93}$ The shareholders' right of initiative with respect to directorial nominations, which does not exist in the American context, is a noteworthy difference in Canadian corporate law. However, this difference does not make it more difficult to argue that Canadian corporate law constitutes directors as independent mediating hierarchs. The shareholder proposal mechanism is not consistently used in Canada. For example, a record number of approximately 80 shareholder proposals were reported for the period between January and September $2005 .^{94}$ Out of these proposals, only three concerned directorial nominations.

\section{Team Production THeory AND THE CANAdian OppRESSION REMEdY}

Part III illustrated how the features of American corporate law that evidence the director primacy norm and suppon a Team Production Theory of American corporate law can also be located in Canadian corporate law. These features of Canadian corporate law free directors of widely-held public Canadian corporations to balance the competing interests of the various corporate stakeholders who make up the corporation. However, in order to fully consider whether Canadian corporate law supports a Team Production Theory, it is necessary to examine the oppression remedy, a potential departing point for the Canadian experience that is not found in American corporate law. ${ }^{\% 6}$

The Canadian oppression remedy has been described as the broadest of the Canadian corporate law remedies. ${ }^{97}$ The oppression remedy is available to the same broad range of complainants as the derivative action on proof of an act or omission, in respect of a

-2 Jbid., s. 137(1.1): CBCR, supro note 86. s. 46.

$93 \quad C B C A$, ibid., s. 150.

9. Shareholder Proposals (2005), online: Shareholder Association for Research and Educalion <www. slare.cu/en/shreliolderdb>.

4) Hid

4h In some American states a stalutory sharelolder oppression remedy exists that is similar to Section 14.30(2)(ii) of the Model Business Corporation Acr, 3d ed. (Englewood Cliffs. N.J.: Aspen Law \& Business, 1996), which provides for juclicial dissolution upon application by a stockholder if "the directors or those in control of the corporation have acted, are acting, or will act in a manner that is illegal, oppressive, or fraudulent." Traditionally, on a finding of oppression in states that have adopted this statulory provision, the court could make a dissolution order for the corpuration. More recently, the alternative of forcing the purchase of minority shares by majority shareholders has been adopted to prevent "oppression of the majority by the minority." In the limiled number of stales where the oppression remedy does exist. the remedy is far more limited both in terms of possible complainants and possible remedies on a linding of oppressien as compared to the Canadian oppression remedy. Sec Deuglus K. Moll, "Shareholder Oppression in Close Copporations: The Unanswered Question of Perspective" (2000) 53 Vand. L. Rev. 749 and Paula J. Dalley, "The Misguided Doctrinc of Stockholder Fiduciary Duties" (2004) 33 Ilofstra L. Rev. 175.

97 820099 (nnario Inc. v. Harold E. Ballard l.sd. (1991), 3 B.L.R. (2d) 123 (Ont. Gen. Div.) at para. 120 [Ballard]. For a discussion of the origins of the oppression remedy, see First Edmonton Place Lid. $v$. 315888 Alherla Lid. (1998), 60 A.L.R. (2d) 122 (Q.B.). 
corporation or its affiliates, that is "oppressive or unfairly prejudicial to or that unfairly disregards the interests of any security holder, creditor, director or oflicer." ${ }^{\circ / 8}$ The oppression remedy is not only intended to protect strict legal rights, but also to protect the expectations of the complainant. ${ }^{99}$ The approach that has most commonly been taken by Canadian courts in interpreting the oppression remedy has been a general lairness standard based on the reasonable expectations of the applicant, rather than on three different standards. ${ }^{100}$ On a finding of oppression, the court has the discretion to choose from 14 prescribed forms of relief or to make the "order it thinks fit."101

A review of the judicial treatment of the oppression remedy illustrates that it has great potential to deal with extra-legal sources of power that can be used to dictate unfair distributional outcomes that are consistent with strict legal rights of the parties involved, but that do not reflect the parties' reasonable expectations. However, in the current context, the broad characterization of the remedy is most accurate with respect to its availability to minority and, in some cases, majority shareholders or to other stakeholders of closely-held corporations. The only comprehensive empirical study of the judicial treatment of the oppression remedy in Canada detailed that of the reported oppression remedy decisions between 1995-2001 only 9 percent, or six cases, involved widely-held public corporations. with the remaining 92 percent of oppression actions litigated in the context of closely-held corporations..$^{102}$ Of the six cases involving widely-held corporations, only two, or 33 percent, were successful, compared to a success rate of 54 percent with respect to closely-held corporations. $^{103}$

In the context of closely-held corporations, the oppression remedy has been used to overcome specific legal rights in cases where the corporation has oppressed the interests and reasonable expectations of the stakeholders seeking relief. Within the context of closely-held corporations, the oppression remedy has not been specifically confined for the benefit of minority shareholders. The oppression remedy was granted to non-minority shareholders of closely-held corporations in 14 percent of the 80 percent of cases where the complainants were shareholders of closely-held corporations. ${ }^{104}$ For example, in both Gandalman

CBCA, supra note 30, s. 241(2).

See, e.g. Wesifair loods Lad. V. Wall (1991), 115 A.R. 34 (C.A.), leave to appeal to S.C.C. relused [1991] 3 S.C.R. xii, recently relerred to in Clarke $v$. Rosshurger, 2001 ABCA 225. 293 A.R. 223.

For a discussion of the standard. sec Jeffrey G. Maclntosh. "Bad laaith and the Oppression Remedy: Uneasy Marriage, or Amicable Divoree?"' (1990) 69 Can. Bar Rev. 276.

CACA, supro note 30. s. 241(3).

Stephanie Ben-Ishai \& Poonam Puri, "The Canadian Oppression Rernedy Judicially Considered: 1995. 2001 (2004) 30 Queen's L.J. 79 at 92.

lbid.

lbid. at 102. 
Investments ${ }^{105}$ and $M . v . H .{ }^{106}$ the plaintiffs were 50 percent shareholders. In both cases, the courts expressed the view that determining whether the behaviour was oppressive required considering the balance of power, which existed between the shareholders, not solely considering the absolute shareholdings. ${ }^{107}$ Canadian courts have also extended the availability of the oppression remedy to a trustee in bankruptcy of a closely-held corporation ${ }^{106}$ and granted the remedy to creditors of closely-held corporations in a number of instances. ${ }^{109}$

If Canadian courts applied the oppression remedy to widely-held public corporations in the same fashion it has been increasingly applied to closely-held corporations, its existence in Canadian corporate law could cut against a Team Production Theory of Canadian corporate law of widely-held public corporations. That is, the central premise of Team Production Theory is that corporate law is designed to free directors from domination by any stakeholder, which allows them to act as mediating hierarchs. However, if the oppression remedy was widely available and consistently used by stakeholders of widely-held public corporations, then a space for directorial discretion may not exist or be necessary. Corporate law could mandate directors to act on behalf of shareholders, but subject to fair treatment of other stakeholders as protected by the oppression remedy.

Peoples leaves open the possibility for the broad use of the oppression remedy by stakeholders of public corporations as it endorses the oft-cited description of the oppression remedy as "the broadest, most comprehensive and most open-ended shareholder remedy in the common law world." 10 Further, the Court held that "the availability of such a broad oppression remedy undermines any perceived need to extend the fiduciary duty imposed on directors by paragraph 122(1)(a) of the $C B C A$ to include creditors." suggests that in future cases the oppression remedy analysis will not require a determination of whether directors have breached their fiduciary duties and that it may be possible to use the oppression remedy to hold directors accountable to individual stakeholders. However, neither position is new and both can be taken as obiter as the case itself did not concern an

Re Gomdalman Imestments Inc. v: Fogle (1985), 52 O.R. (2d) 614 (H.C.J.) [Gandalman Imves/ments]. In Gandalman Imessments, one of the SO percent sharcholders acted as the secretary-Ireasurer and carried on the business of the company, while the other unsuccessfully attempted to be appointed a director and sought a remedy under s. 247 of the Ontario Business Corporations Act, 1982, S.0. 1982, c. 4. A preliminary objection was raised on the ground that the oppression remedy was only available to minority shareholders. The court held that a "complainant" could include "any security liolder" and, as such, is not linited to only minority shareholders.

(1993), 15 O.R. (3d) 721 (Gen. Div.) [M. v. II.]. The plaintiff in this case was a 50 pereent shareholder in two businesses with a partner, but was being excluded from business operations due to the dissolution of a romantic relationship. The plaintiff sought relief pursuant to s. 248 of the $C B C A$ and succeeded on the basis that the defendant had excluded the plaintiff from at least one of the businesses and ignored her expectations. Gandalman Investments, supra note 105 at para. 7 ; II. :. H., ibid. at 728-729. Olympia d York Developments Led. (Truster' of) v. Olympias \& York Realy! Corp. (2001). 16 B.L.R. (3d) 74 (Ont. Sup. Ct. J.). Eakn (1993) L.da. v. Omario (2001). 54 O.R. (3d) 161 (C.A.). 
oppression action. ${ }^{1 / 2}$ Importantly, practical obstacles also stand in the way of the oppression remedy developing in a way that displaces directors' existing legal role in Canadian public corporations as mediating hierarchs.

The direction in Peoples that the judicial application of the oppression remedy is to be divorced from a fiduciary duty analysis has been given by lower courts in the past without significant impact on how the judiciary has engaged in their analysis of oppression actions. ${ }^{13}$ As a practical matter, judges draw on their overall knowledge of corporate law in dealing with the relatively few oppression actions that they are faced with each year. ${ }^{1 / 4}$ As a result, the judicial treatment of the oppression remedy has frequently drawn from the case law on breach of statutory duties and imported the analysis of concepts such as the "best interests of the corporation" and the "business judgment rule" from this case law.

For example, in Ballard, ${ }^{115}$ Farley J. granted the oppression remedy to a minority shareholder of a closely-held corporation. Justice Farley referenced the Supreme Court's definition of a corporation in Ringuet v. Bergeron, ${ }^{116}$ holding that

while it would be appropriate for a director to consider the individual desires of one or more various shareholders ... it would be inappropriate for that director to only consider the interests of certain shareholders and to either ignore the others or worse still act in a way detrimental to their interests. The safe way to avoid this problem is to have directors act in the best interests of the corporation. ${ }^{117}$

The Ballard decision has been frequently cited and followed by Canadian courts applying the oppression remedy ${ }^{\prime 1 x}$ and was referred to in the Peoples discussion of the fiduciary duty, ${ }^{119}$ reflecting how difficult it is for the judiciary to divorce their understanding of the Canadian fiduciary duty from their analysis and application of the oppression remedy.

Rather, the case was based on the issue of whether directors owe a duty to creditors. The Irustec, representing the interests of the creditors, sued the directors for an alleged breach of the duties imposed by s. $122(1)$ of the $\angle B C A$. In its analysis, the Court recognized that, according to art. 300 of the C.C.Q. and s. 8.1 of the Imerpretation Act, R.S.C. 1985. C. 1-21, the civil law serves as a supplementary source of law to federal legislation. The $C B C A$ does not entitle creditors to sue directors directly for breach of their duties, and so the Coun deemed it appropriate to have recourse to the C.C.Q. to establish how rights grounded in a lederal statute should be considered in Quebec. The Court also looked to the C.C.Q. to determint how s. $122(1)$ of the $C B C$ A can be harmonized with the principles of civil liability. Sec ibid. at paras. 29-30.

113 See, e.g., Brom Imlestments Led. v. KeepRite Inc. (1991). 3 O.R. (3d) 289 (C.A.) affirming (1987), 60 O.R. (2d) 737 (H.C.), where the Court of $A$ ppeal held at 301:

It must be recalled that in dealing with s. 234, the impugned acts, the results of the impugned acts. the protected groups, and the powers of the court to grant remedies are all extremely broad. To import the concipt of breach of fiduciary duty into that statutory provision would not only complicate its interpretation and application, but could be inimical to the statutory fiduciary duty imposed upon directors in s. $117(1)$ (now s. 122(I)) of the $C B C A$ ). with the oppression remedy on is merits between January 1945 and November 2001. Ballard, sumwa nole 97, alf'd (1991), 3 B.L.R. (2d) 113 (Div. Cl.).

[1960] S.C.R. 672.

Ballard, supra note 97 at para. 105.

118 See, eg., Riverstar Inc. v. Hookenson, 2004 ABQB 916, [2004] A.J. No. 1500 (QL): McAleer, supro note 41: and Deluce Holdings Inc. v. Air Canada (1992), 12 O.R. (3d) I3I (Gen. Div.). 
In addition, while Canadian courts have recognized that the oppression remedy is a broad and flexible tool designed to protect the interests of corporate stakeholders in a variety of ways, they have also been influenced by the business judgment rule and its application to the statutory duty of care. For example, in Re Ferguson and Imax Systems Corp..${ }^{120}$ the Ontario Court of Appeal held that it was imperative that the oppression remedy be applied in a manner that balances the protection of stakeholders and the ability of management to conduct business in an efficient manner. More recently, in Catalyst Fund General Partmer I linc. v. Hollinger $/ n c .{ }^{121}$ when Campbell J. invoked the oppression remedy to remove the directors of Hollinger, he held that this was an extreme form of judicial intervention that should be a measure of last resort where directors were "motivated by putting their interests first, not those of the company."'23

A further limitation on the oppression remedy disturbing other aspects of Canadian corporate law that shield directors from domination by individual stakeholders is that, similar to any form of litigation, a significant impediment to recourse through the oppression remedy is the financial resources of the litigants. Recent Canadian case law has held that a class proceeding founded upon an oppression action under the $C B C A$ can be maintained. ${ }^{123}$ However, the possibility for oppression remedy class proceedings is limited by the requirement that all members of the class must demonstrate that they have common reasonable expectations. ${ }^{124}$

12) (1983), 430.R. (2d) 128 (C.A.) at 137. This was an appeal alter (he application for relief was dismissed under s. 234 of the Cameda Business Corporations Act, S.C. 1974-5, c. 33. The appellant claimed that the corporation and the directors had, by organizing a special meeting to vole on a resolution to amend its articles to reorganize its capital, acted in a manner that was oppressive, unfairly prejudicial, or unfairly distegarded her interests as a security holder. On appeal. Brooke J.A. found for the appellant and granted her relief for oppression.

(2004), I B.L.R. (4th) 186 (Ont. Sup. C1. J.). This was an application by Catalyst against Hollinger Inc., where it sought the removal of a majority of the company's board of directors pursuant to the power granted under the oppression remedy. The allegations against those directors concerned the fact that a $\$ 1.1$ million loan made by Hollinger Inc. to its parent Ravelston had not been authorized by the Board of Hollinger Inc. at the time it was made in June 2004. Further, the existence of the loan had not been disclosed during Catalyst's first anplicution heard earlier by the court.

1.: $\quad$ bid. at para. 83.

133 Stern v. Imasco) (1999), 1 B.L.R. (3d) 198 at para. 78 (Ont. Sup. Ci. J.) [Stern]. In Stern, Daniel Stern initiated an action, on behalf of himself and as representative of a class that included all shareholders (other than the defendants). claiming that a proposed transaction was oppressive and that it constiluted a breach of liduciary duties owed by the individual defendant directors to Imasco's sharcholders. Although the Cour dismissed the motion. Cumming J. found that Stem's claim for oppression was a complaint only against the corporation rather than the directors, and that an oppression action could form a basis for a class procecding, despite the lact that there are many elements of a class proceeding that are not found in an action for oppression.

12. Shaw v. BCE Inc., [2003] O.J. No. 2695 (QL) (Sup. Ct. J.) [Shaw]. In Shaw, BCE filed a motion that the Statement of Claim be struck out and dismissed against BCF on the ground that it disclosed no reasonable cause of action against BCE. In the Statement of Claim. Shaw pled two causes of action: negligent mistepresentation and oppression. Justice Farley found that Shaw did not make out a reasonable cause of action for oppression, further stating that Shaw was not an appropriate representative plaintiff since his personal "wish list" of expectations were not reasonable and were not shared by all of the shareholders. It should be noted that Shaw anended the Statenent of Claim and BCE again filed a motion to strike on the same grounds. In Shaw v. BCE Inc. (2003), 42 B.L.R. (3d) 107 (Ont. Sup. Ct. J.), affd (2004), 49 B.L.R. (3d) I (Ont. C.A.), Farlcy J. again struck the amended Statement of Claim as failing to disclose a reasonable cause of action in oppression. 


\section{Conclusion}

This article has used the recent Supreme Court of Canada decision Peoples, ${ }^{125}$ which has attracted a great deal of interest among academic and lawyer commentators, to challenge the underlying assumption that Canadian corporate governance debates are currently operating on. That is, Canadian corporate law of public corporations currently rellects a principleagent, shareholder primacy model, and Peoples represents a departure from this model. This article has challenged this understanding of Canadian corporate law by illuslrating how key features of Canadian corporate law, including Peoples, are consistent with a director primacy norm and the Team Production Theory of corporate law developed in the American context.

By illustrating that the current state of Canadian corporate law frees directors of widelyheld public companies to balance the competing interests and maintain the confidence of the various stakeholders of such corporations, this article has provided the descriptive context for beginning to ask a range of normative questions. In particular, is the legal role of directors of Canadian corporations consistent with the role that they actually play? In addition, is it possible and/or desirable for directors of Canadian corporations to play this role given the current composition of corporate boards? Further empirical work needs to be done to consider the first question and the issue of the relative importance of law in this context.

The second question concerns a central fairness issue that arises from a Team Production Theory of Canadian corporate law. That is, while directors are constituted as independent mediating hierarchs in law, they are overwhelmingly drawn from the ranks of powerful corporate stakeholders, including shareholders and creditors. Blair and Stout suggest that like the judiciary or the police, it is possible for directors to play an independent role, even if they are drawn from a certain group of stakeholders. ${ }^{126}$ As recognized by Farley J. in Re Siclco, ${ }^{127}$ the role of the corporate director as currently conceived in practice is quite different than that of a professional acting in the public interest. As currently constituted, a directorship is a business role. Directors will have a range of extra-legal incentives to favour powerful stakeholder interests over those of more politically vulnerable stakeholders, such as employees, in a range of situations. For example, Millon has argued that in a widely-held public corporation, shareholders will always have a lower cost exist option than employees, who have already made team-specific investments in non-transferable knowledge and skills. ${ }^{128}$ These unequal power relations within public corporations translate into employees extracting minimal surpluses, despite increased productivity demonstrated by indexes, such as the Dow Jones Industrial Index, rapidly increasing in value. ${ }^{124}$ On this basis, Millon argues that shareholders will always win the rent allocation contest. ${ }^{130}$

Supra note 1.

TP'T. supra note 12 at 253. Slout and Blair have developed this argument further in their consideration of director incentives. Sec in particular: Margarel M. Blair \& Lynn A. Stout. "Specilic Investment and Comorate Law" Lur. Bus. Org. L. Rev. [Fortheoming], online: SSRN <htup://ssm.convabstract $869010>$ and Lynn Stout, "The Sharcholder as Ulysses," (200)3) 152 U. "Ha. L.Rev. 667 at $686-87$.

Supra nole 69.

Millon, supra note 29 at 1042.

Jbid. at 1029.

lhid. 
In considering whether the independent hierarch legal role for directors is the most desirable model, a question that will need to be considered in the Canadian context is if and how this role can be given meaning in practice. One possibility is to create a class of professional independent mediating hierarchs, or to "professionalize" directors through education. Director education has already been recognized as a mechanism for dealing with the increasingly complex nature of the Canadian business climate, as well as the dynamic role that directors are expected to play in this climatc. ${ }^{131}$ Both commentators and members of the legal community have acknowledged a link between board competence and corporate success. ${ }^{132}$ Even directors themselves have realized that limitations on their ability to participate in meaningful and strategic discussions are due to gaps in their knowledge and understanding about both the role of the board as well as the corporation for which they serve. $^{133}$

At the same time, there are a number of challenges that will need to be addressed in adopting this approach. Successful educational programs may be restricted by the limited term of directorships, typically to a maximum of three years. ${ }^{134}$ To address this concern, any director training must be concise and time-sensitive, and also broad enough in scope to allow transferability between boards. Director education might also contribute to complacency about board effectiveness by giving a false sense of security about the competence of individual directors. ${ }^{133}$ As well, if director training becomes a prerequisite, this could stifle board diversification by limiting qualified candidates, ${ }^{136}$ thereby limiting board effectiveness based on the rationale that the more diverse the board is, the more capable it will be to play an independent mediating hierarch role. ${ }^{137}$ Finally, the risk of high costs associated with director education could further limit access to such education and reduce diversity of corporate boards.

131 TSE. Joint Committec on Corporate Govemance, Interim Report, “Beyond Compliance: Building a (iovernance Culture" (March 2001), online: Chartered Accountants of Canada <www.cica/ca/multimediu/Download_Library/Research_Guidance/Risk_Management_Governance// March 16E_InterimReport.pdt>: NASDAQ. News Relcase. "NASDAQ and Corporate Board Member Magazine $\bar{R}$ oll Out Third Series of Educational Board Governance Webcasts" (April 2003), onlinc: NASDAQ Stock Market <http://r.nasdaq.com/releasedetail.cfm?relcaseid=177688>.

15: P. Michacl Maher \& Malcolm C. Munro, "Capturing Board Potential: A Value Adding Approach," online: (2003) 68:1 Ivey Business Journal <www.iveybusinessjournal.com/view_article.asp?int Article_ID-438>.

Ibid.

134 TSE, "Report on Corporate Governance, 1999; 5 Years to the Dey," online: European Corporate Governance Institute <www.ecgi.org/cokles/documents/5years.pdis.

lbid.

i in N. Fondas \& S. Sassalos, "A Diflerent Voice in the Boardroom: How the Presence of Women Directors Affects Board Influence over Management" (2000) 12:2 Global Focus 13.

is Lynne L. Dallas, "The New Managerialism and Diversity on Corporate Boards of Directors" (2002) 76 Tul. L. Rev. 1363. 